\title{
EFFECT OF AGE ON PHARMACOKINETICS OF DANOFLOXACIN IN EGYPTIAN BUFFALO CALVES
}

\author{
A.A.M. El-Gendy and M.A. Tohamy \\ Pharmacology Dep., Faculty of Vet . Med., Beni-suef University
}

\begin{abstract}
The pharmacokinetic profile of danofloxacin, a fluoroquinolone antibacterial was studied in one, two-months and one year old Egyptian buffalo calves following a single intravenous and intramuscular administration of $1.25 \mathrm{mg} \mathrm{kg}^{-1}$ b.wt. in a cross over study with 15-day wash out period. Drug concentrations in serum were determined by microbiological assay technique. After i.v administration the serum concentration-time curve of danofloxacin was best fitted using two-compartment open model. The drug was rapidly distributed as indicated by short distribution half-lives $\left(t_{1 / 2(\alpha)}\right)$ of 0.093, 0.117 and $0.194 \mathrm{~h}$ in one, two-months and one year old calves, respectively. The elimination half-life was relatively longer in one- and two-months than in one year old calves $\left(t_{1 / 2(\beta)}\right) 5.802$ compared to 4.941 and $3.795 \mathrm{~h}$., respectively. The volumes of distribution at steady-state (Vdss) 1.259, 1.347 and $\left.1.490 \mathrm{~L} \mathrm{~kg}^{-1}\right)$, total body clearance $\left(\mathrm{Cl}_{B}\right)=0.155,0.195$ and $\left.0.280 \mathrm{~L} \mathrm{~kg}^{-1} \mathrm{~h}^{-1}\right)$ and mean residence time $(M R T=8.127,6.886$ and $5.334 \mathrm{~h})$ were recorded in the three ages, respectively. Ara under the plasma concentration vs. time curve(AUC) was decreased with age 8.564, 6.651 and 4.615 ug $\mathrm{ml}^{-1} \mathrm{~h}^{-1}$ in the three ages, respectively). Following intramuscular administration, the absorption half-life (t/2(ab)) was 0.421, 0.462 and $0.425 \mathrm{~h}$ in the three ages, respectively. The maximum serum concentrations $\left(C_{\max }\right)$ of $0.541,0.434$ and $0.363 \mathrm{ug} \mathrm{ml}^{-1}$ were attained after $\left(t_{\max }\right) 1.853,1.810$ and $1.712 \mathrm{~h}$ in the three ages, respectively. The elimination half-life ( $\left.t_{1 / 2(2 l)}\right)$ and MRT values of danofloxacin were longer in one-month old calves compared to two months and one year old calves. The systemic intramuscular bioavailabilities were 96.672, 98.136 and $94.366 \%$, while the in-vitro serum protein-binding tendencies were 6.678, 9.176 and $13.572 \%$, for one, two-months old and one year old calves, respectively.
\end{abstract}




\section{INTRODUCTION}

Danofloxacin is a fluoroquinolone antibacterial drug that was developed specifically for veterinary use. Its antimicrobial activity spectrum is wide and includes most gram-negative and some gram-positive bacteria, Mycoplasma and intracellular pathogens, such as Brucella and Chlamydia species but has only limited activity against anaerobic organ-isms (Hannan et al., 1989; Wolfson and Hooper 1989; Neu 1991 and Appelbaum and Hunter 2000). Like other fluoroquinolones, it acts as bacteri-cidal antimicrobial by inhibiting bacterial DNA gyrase (Brown 1996).

Because of lack of literature on kinetic behavior of danofloxacin in buffaloes, the aim of the present study was to investigate the effect of age on the pharmacokinetics of the drug in buffalo calves following intravenous and intramuscular administration.

\section{MATERIAL AND METHODS}

\section{Drug:}

Danofloxacin was supplied as an injectable solution $\left(\right.$ Advocin $\left.^{\circledR}\right)$ by animal health division Pfizer Company, Cairo, Egypt.

\section{Animals:}

Five healthy Egyptian buffalo calves each of one month old calves (weighing 40-50 kg b.wt.), two months old calves (weighing 60-80 kg b.wt.) and one year old calves (weighing 200-300 kg b.wt.) were used. The study was carried out in the Animal Farm, Faculty of Veterinary Medicine, Beni-Suef University. They were kept under good hygienic 
condition. None of the animal was treated with any antimicrobials for one month prior to the trial. One and two months old animals were fed milk and barseem while one-year old animals were fed barseem, hay and water ad- libitum.

\section{Experimental design:}

Calves were injected $1.25 \mathrm{mg} \mathrm{kg}^{-1}$ b.wt. danofloxacin according to Aliabadi and Lees (2001 and 2003); Aliabadi et al.,( 2003 ${ }_{a}$ and $b$ ) via single i.v. and i.m. administration in cross over study with 15 days interval to ensure complete clearance of the drug. Blood samples were collected via vein puncture from jugular vein before and at 0.083, 0.167, $0.25,0.50,1,2,4,6,8,12$ and 24 hour post-administration. Blood samples were left to clot then centrifuged at 3000 r.p.m for 15 minutes to obtain clear sera that were kept in deep freeze at $-20^{\circ} \mathrm{c}$ until assayed.

\section{Drug bioassay:}

Serum concentrations were detected by the microbiological assay technique as described by Bennett et al., (1966) using Escherichia coli (ATCC 25922) as a test organism. The minimal detectable limit was $0.125 \mathrm{ug} \mathrm{ml}^{-1}$, the standard curve and protein binding tendency were determined in vitro using antimicrobial free calves serum and phosphate buffer saline $(\mathrm{pH}$ 7.2). The difference of inhibition zone diameter between serum and buffer was used to calculate the protein binding tendency of danofloxacin according to Craig and Suh (1980) by the following equation:-

$$
\text { Protein binding } \%=\frac{\text { Zone of inhibition in buffer }- \text { Zone of inhibition in serum }}{\text { Zone of inhibition in buffer }} \times 100
$$




\section{Pharmacokinetic analysis:}

Serum concentrations $\left(\log _{10}\right)$ versus time curve were generated and best fitted by the aid of computer poly-exponential curve stripping program (R-strip, Micromath, Scientific software, USA). Data from each animal were fitted individually and the pharmacokinetic variables were computed by the aid of the software program. The hybrid rate constants of distribution and elimination phase ( $\alpha$ and $\beta$ ), first order absorption and elimination rate constants $\left[\mathrm{K}_{\mathrm{ab}}\right.$ and $\left.\mathrm{K}_{\mathrm{el}}\right]$ and the corresponding extrapolated zero time intercepts (A and B), absorption, distribution and elimination half lives $\left(\mathrm{t}_{1} / 2(\mathrm{ab}), \mathrm{t}_{1} / 2(\alpha), \mathrm{t}_{1} / 2(\beta)\right.$ and $\left.\mathrm{t}_{1 / 2(\mathrm{el})}\right)$, transfer rate constants $\left(\mathrm{K}_{12}\right.$ and $\left.\mathrm{K}_{21}\right)$, mean residence time (MRT), maximum serum concentration $\left(\mathrm{C}_{\max }\right)$ and time to be achieved $\left(\mathrm{t}_{\max }\right)$, volume of central compartment $\left(\mathrm{V}_{\mathrm{c}}\right)$, apparent volume of distribution at steady state $\left(\mathrm{Vd}_{\mathrm{ss}}\right)$, total body clearance $\left(\mathrm{Cl}_{\mathrm{B}}\right)$ were calculated according to Baggot (1978). Area under the serum concentration-time curve (AUC) was calculated by trapezoidal rule, whereas the intramuscular bioavailability $(\mathrm{F})$ was calculated according to the following equation: $\left(\mathrm{AUC}_{\mathrm{i} . \mathrm{m}} / \mathrm{AUC}_{\mathrm{i} . \mathrm{v}}\right) \times 100$, (Gibaldi and Perrier 1982). The statistical analysis were carried out according to (Snedecor and Cochran 1976).

\section{RESULTS}

The pharmacokinetic parameters after i.v. and i.m. administration of danofloxacin in one-month, two-months old and adult Egyptian buffalo calves are prescribed in tables (1 and 2). The mean serum concentration-time curves following i.v. and i.m. administration for the three ages were depicted in figures (1 and 2), respectively. 
The significant differences were determined in pharmacokinetic behavior of danofloxacin in one-month and two-months old calves when compared with that of adult calves. Danofloxacin was rapidly distributed after i.v. injection in buffalo calves as indicated by short distribution half lives $\left(\mathrm{t}_{0.5(\alpha)}\right)$ of $0.093,0.117$ and $0.194 \mathrm{~h}$ in one-month, two-months old and adult calves, respectively. The drug was slowly eliminated in buffalo calves with elimination half-life $\left(\mathrm{t}_{0.5(\beta)}\right)$ was significantly longer in one and two- months (5.802 and $4.941 \mathrm{~h}$ ) than in one year old calves (3.795 h). Volume of distribution at steady-state was significantly smaller in one- and two-months old calves $\left(\mathrm{Vd}_{\mathrm{ss}}=1.259\right.$ and $\left.1.347 \mathrm{~L} \mathrm{~kg}^{-1}\right)$ compared to adult calves $\left(\mathrm{Vd}_{\mathrm{ss}}=1.490 \mathrm{~L} \mathrm{~kg}^{-1}\right)$. Also, there was a significantly longer mean residence time $(8.127,6.886$ and $5.334 \mathrm{~h}$ in one-,followed by two-months old then one year old calves), respectively.

After intramuscular administration, danofloxacin was rapidly absorbed in buffalo calves. The mean absorption half-life $t_{0.5(a b)}$ was $(0.421,0.426$ and $0.425 \mathrm{~h})$ for two-months and one year old calves, respectively. The maximum serum concentrations $\left(\mathrm{C}_{\max }\right)$ were significantly higher in one-month old calves $(0.541)$ followed by twomonths (0.434) than one year old calves (0.363) ug $\mathrm{ml}^{-1}$ and achieved after $\left(t_{\max }\right) 1.853,1.810$ and $1.712 \mathrm{~h}$., respectively. The elimination halflife $\left(\mathrm{t}_{0.5(\mathrm{e})}\right)$ and MRT were significantly longer in one-month old (8.325 and $12.565 \mathrm{~h}$ ) and two- months old (7.978 and $12.039 \mathrm{~h}$ ) than in one year old calves (6.540 and $9.974 \mathrm{~h}$ ), respectively. The values of AUC were significantly decreased with age after i.v. and i.m. administration. The invitro protein binding tendencies were $(6.678,9.176$ and 13.572) and systemic bioavailabilities following i.m. administration were (96.672, 98.136 and $94.136 \%$ ), respectively. 
Table (1): Mean $( \pm$ SE) kinetic parameters of danofloxacin following a single intra-venous administration of $1.25 \mathrm{mg} \mathrm{kg}^{-1}$ b.wt in buffalo calves $(n=5)$.

\begin{tabular}{|c|c|c|c|c|}
\hline Parameter & Unit & onemonth & Two month & One year \\
\hline $\mathrm{C}_{\mathrm{p}}{ }^{\mathrm{O}}$ & ug $\mathrm{ml}^{-1}$ & $2.701^{\mathrm{a}} \pm 0.141$ & $2.180^{\mathrm{b}} \pm 0.087$ & $1.229^{c} \pm 0.083$ \\
\hline $\mathrm{A}$ & ug ml $l^{-1}$ & $1.766^{\mathrm{a}} \pm 0.256$ & $1.315^{\mathrm{a}} \pm 0.106$ & $0.434^{\bar{b}} \pm 0.03$ \\
\hline$\alpha$ & $\mathrm{h}^{-1}$ & $7.420^{\mathrm{a}} \pm 0.324$ & $5.939^{\mathrm{b}} \pm 0.476$ & $3.581^{\mathrm{c}} \pm 0.204$ \\
\hline $\mathrm{t}_{0.5(\alpha)}$ & $\mathrm{h}$ & $0.093^{\mathrm{b}} \pm 0.051$ & $0.117^{\mathrm{a}} \pm 0.01$ & $0.194^{\mathrm{a}} \pm 0.012$ \\
\hline $\mathrm{B}$ & ug ml ${ }^{-1}$ & $0.936 \pm 0.051$ & $0.865 \pm 0.0561$ & $0.795 \pm 0.0685$ \\
\hline$\beta$ & $\mathrm{h}^{-1}$ & $0.119 \pm 0.001$ & $0.140 \pm 0.0143$ & $0.183 \pm 0.03$ \\
\hline $\mathrm{t}_{0.5(\beta)}$ & $\mathrm{h}$ & $5.802^{\mathrm{a}} \pm 0.326$ & $4.941^{\mathrm{a}} \pm 0.143$ & $3.795^{\mathrm{b}} \pm 0.314$ \\
\hline $\mathrm{k}_{12}$ & $h^{-1}$ & $4.556^{\mathrm{a}}+0.320$ & $3.297^{b} \pm 0.156$ & $1.108^{c} \pm 0.071$ \\
\hline $\mathrm{k}_{21}$ & $h^{-1}$ & $2.649 \pm 0.1957$ & $2.441 \pm 0.1320$ & $2.381 \pm 0.094$ \\
\hline $\mathrm{K}_{\mathrm{el}}$ & $\mathrm{h}^{-1}$ & $0.335 \pm 0.036$ & $0.341 \pm 0.033$ & $0.275 \pm 0.014$ \\
\hline $\mathrm{Vc}$ & $\mathrm{L} \mathrm{kg}^{-1}$ & $0.463^{\mathrm{c}} \pm 0.038$ & $0.573^{\mathrm{b}} \pm 0.039$ & $1.017^{\mathrm{a}} \pm 0.083$ \\
\hline $\mathrm{Vd}_{\mathrm{ss}}$ & $\mathrm{L} \mathrm{kg}^{-1}$ & $1.259^{\mathrm{b}} \pm 0.181$ & $1.347^{\mathrm{b}} \pm 0.092$ & $1.490^{\mathrm{a}} \pm 0.064$ \\
\hline $\mathrm{Cl}_{\mathrm{B}}$ & $\mathrm{L} \mathrm{kg}^{-1} \mathrm{~h}^{-1}$ & $0.155^{\mathrm{a}} \pm 0.023$ & $0.195^{\mathrm{b}} \pm 0.037$ & $0.280^{\mathrm{b}} \pm 0.03$ \\
\hline AUC & ug $\mathrm{ml}^{-1} \mathrm{~h}^{-1}$ & $8.564^{\mathrm{a}} \pm 0.6395$ & $6.652^{\mathrm{b}} \pm 0.237$ & $4.615^{\mathrm{c}} \pm 0.218$ \\
\hline MRT & $\mathrm{h}$ & $8.127^{\mathrm{a}} \pm 0.202$ & $6.886^{\mathrm{b}} \pm 0.419$ & $5.334^{\mathrm{c}} \pm 0.331$ \\
\hline
\end{tabular}

a,b,c Means with different superscripts are significantly different $(\mathrm{p}<0.05)$.

Table (2): Mean $( \pm \mathrm{SE})$ kinetic parameters of danofloxacin following a single intra-muscular administration of $1.25 \mathrm{mg} \mathrm{kg}^{-1}$ b.wt in buffalo calves $(n=5)$.

\begin{tabular}{||l||l||c||c||c||}
\hline \multicolumn{1}{|c||}{ Parameter } & \multicolumn{1}{|c|}{ Unit } & 1-month old & 2-month old & Adult \\
\hline \hline $\mathrm{k}_{\mathrm{ab}}$ & $\mathrm{h}^{-1}$ & $1.648 \pm 0.091$ & $1.620 \pm 0.039$ & $1.631 \pm 0.043$ \\
$\mathrm{t}_{0.5(\mathrm{ab})}$ & $\mathrm{h}$ & $0.421^{ \pm} \pm .012$ & $0.426 \pm 0.033$ & $0.425 \pm 0.011$ \\
$\mathrm{~K}_{\mathrm{el}}$ & $\mathrm{h}^{-1}$ & $0.083^{\mathrm{b}} \pm 0.007$ & $0.087^{\mathrm{b}} \pm 0.002$ & $0.106^{\mathrm{a}} \pm 0.022$ \\
$\mathrm{t}_{0.5(\mathrm{el})}$ & $\mathrm{h}$ & $8.325^{\mathrm{a}} \pm 0.46$ & $7.978^{\mathrm{b}} \pm 0.34$ & $6.540^{\mathrm{c}} \pm 0.79$ \\
$\mathrm{C}_{\max }$ & $\mathrm{ug} \mathrm{ml} l^{-1}$ & $0.541^{\mathrm{a}} \pm 0.02$ & $0.434^{\mathrm{b}} \pm 0.014$ & $0.363^{\mathrm{c}} \pm 0.028$ \\
$\mathrm{t}_{\max }$ & $\mathrm{h}$ & $1.853^{\mathrm{a}} \pm 0.086$ & $1.810^{\mathrm{b}} \pm 0.113$ & $1.712^{\mathrm{c}} \pm 0.066$ \\
$\mathrm{AUC}$ & $\mathrm{ug} \mathrm{ml} l^{-1} \mathrm{~h}^{-1}$ & $8.279^{\mathrm{a}} \pm 0.427$ & $6.528^{\mathrm{b}} \pm 0.80$ & $4.355^{\mathrm{c}} \pm 0.143$ \\
$\mathrm{MRT}$ & $\mathrm{h}$ & $12.565^{\mathrm{a}} \pm 0.97$ & $12.039^{\mathrm{a}} \pm 1.10$ & $9.974^{\mathrm{b}} \pm 0.830$ \\
$\mathrm{~F}$ & $\%$ & $96.672 \pm 7.77$ & $98.136 \pm 9.27$ & $94.366 \pm 8.23$ \\
$\mathrm{IBD}$ & $\mathrm{h}$ & $23.989 \pm 2.07$ & $22.973 \pm 0.97$ & $21.014 \pm 1.57$ \\
\hline
\end{tabular}

a,b,c Means with different superscripts are significantly different $(\mathrm{p}<0.05)$.

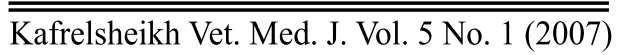


Effect Of Age On Pharmacokinetics Of Danofloxacin ...
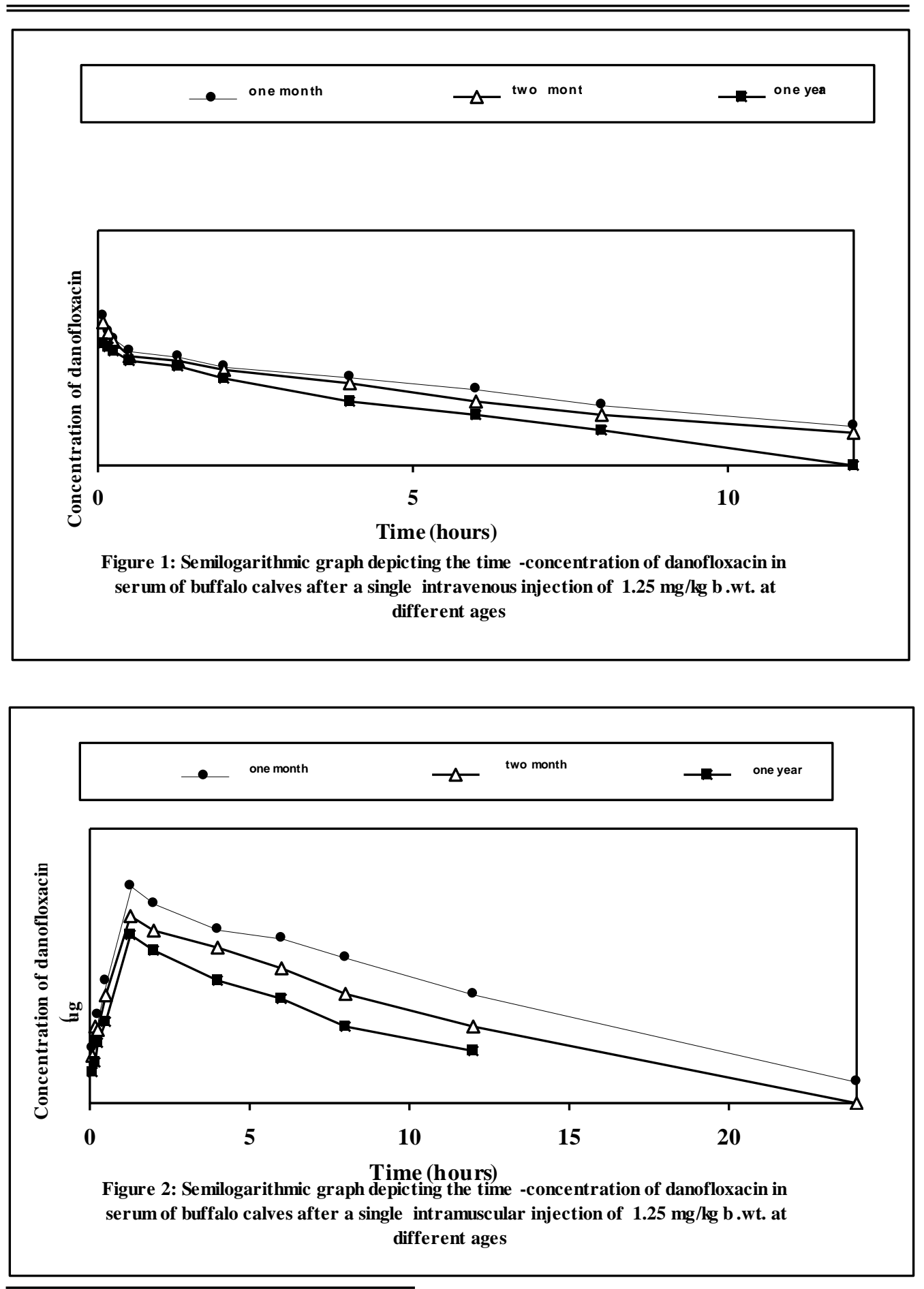

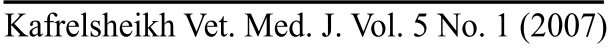




\section{DISCUSSION}

Several studies have established pharmacokinetic data for danofloxacin in farm animals species, including cattle, sheep, goats, camels, chickens and pigs. However, the present publication is to provide similar data for buffalo calves at different ages. Drugs administered to neonatal food-producing animals(cattle,sheep and goats)may exhibit significantly different pharmacokinetic behaviour characteristics than they do in adult animals of the same species (Kietzmann and Loscher 1990). Age-related changes in the pharmacokinetics have been observed for quinolones in ruminant species (Mevius et al., 1990; Thomas et al., 1994; Gips and Soback, 1996; Gonzalez et al., 1997; Kaartinen et al., 1997).

The serum concentration time curve of danofloxacin after IV administration in buffalo calves at different ages could be adequately described using a two-compartment model, this was agreed with findings in goats (Atef et al., 2001), sheep (Aliabadi et al., 2003 ${ }_{\text {a }}$ ) and horse (Fernandez-varon et al., 2006) and led to the same conclusion of initial rapid distribution phase followed by a slower elimination phase. Danofloxacin was distributed rapidly and widely in the body of calves, as evidenced by short $\mathrm{t}_{0.5(\alpha)}$ (ranged from 0.093-0.194 $\mathrm{h}$ ) and large $\mathrm{Vd}_{\mathrm{ss}}$ (ranged from 1.259-1.490 $\mathrm{L} \mathrm{kg}^{-1}$ ). Similar results were recorded for the drug in goats, calves, sheep and camels (Atef et al., 2001; Aliabadi and Lees, 2003; Aliabadi et al., 2003 ${ }_{a}$ and $b$ ), respectively.

Danofloxacin administered i.v. to calves was eliminated slowly with an elimination half-life $\left(\mathrm{t}_{0.5(\beta)}\right)$ ranged from 3.795-5.802 $\mathrm{h}$. This value is nearly similar to those reported in goats (3.35 and $4.67 \mathrm{~h}$ ), sheep 
(3.39 h) and camels (5.37 h) (Mckellar et. al, 1998; Aliabadi and lees, 2001 and Aliabadi et al., 2003 ${ }_{a}$ and ${ }_{b}$ ). This indicated a slow final disappearance of the drug from the blood.In this respect,fluoroquinolones have a long serum half-life making them suitable for once or twice a day administration (Hooper and Wolfson 1985; Vancutsem et al., 1990).

Total body clearance of danofloxacin in one- and two-months old calves $\left(\mathrm{Cl}_{\mathrm{B}}=0.155\right.$ and $\left.0.195 \mathrm{~L} \mathrm{~kg}^{-1} \mathrm{~h}^{-1}\right)$ were significantly lower than that in adult calves $\left(\mathrm{Cl}_{\mathrm{B}}=0.202 \mathrm{~L} \mathrm{~kg}^{-1} \mathrm{~h}^{-1}\right)$, which possibly may be the result of the poor development of biotransformation and excretory processes in the young calves compared to adult calves (Short and David,1970 and Short,1984 ).The slow elimination of the drug from the body of calves could be explained by the lower rate of clearance. Drug metabolizing enzymes are ill developed in neonatal calves this suggestion is supported by previous data reported by Thomas et al. (1994) for marbofloxacin in preruminant calves, bile account for $10 \%$ of marbofloxacin excretion in preruminant while in ruminant calves reach $45 \%$ of the excreted drug .Similar increase in body clearance with age have been observed for marbofloxacin between 3 weeks old and adult cattle.

The apparent volume of distribution at steady-state $\left(\mathrm{Vd}_{\mathrm{ss}}\right)$ is an accurate indication of the diffusion of the drug into the body tissues (Galinsky and Svensson 1995). The distribution of danofloxacin in the body of buffalo calves recorded in this study was more than unity (> one $\mathrm{L} \mathrm{kg}^{-1}$ ) following i.v administration (1.259-1.49 $\mathrm{L} \mathrm{kg}^{-1}$ ), indicated that the drug was extensively distributed to extra-vascular tissues. This result supported by Baggot (1978). Also, a low volume of central compartment $\left(\mathrm{V}_{\mathrm{c}}\right.$ ranged from $0.463-1.017 \mathrm{~L} \mathrm{~kg}^{-1}$ ) and high volume of distribution at 
steady state $\left(\mathrm{Vd}_{\mathrm{ss}}\right.$ ranged from 1.259-1.49 $\left.\mathrm{L} \mathrm{kg}^{-1}\right)$ indicated that the peripheral compartment is the major compartment for danofloxacin distribution at steady state. The volume of distribution of danofloxacin in one-year old buffalo calves is relatively large (1.4.9 $\mathrm{L.kg}^{-1}$ ), nearly similar results were recorded for danofloxcin in ewe (1.9 L. $\left.\mathrm{kg}^{-1}\right)$ (Shem et al., 1997) and goats (1.42 L. $\left.\mathrm{kg}^{-1}\right)$ (Atef et al., 2001). Also, $\mathrm{Vd}_{\mathrm{ss}}$ was significantly increased related to age $(1.259,1.347$ and 1.49) for one, two-months and one year old buffalo calves. This result was in agreement with that reported for marbofloxacin in goats (Waxmans et al. 2004). This result could be attributed to different proportion of water, body fat and development of fore stomach. In neonate mammals, body water forms $70-75 \%$ of weight but in adult forms $60 \%$ of weight, while body fat increases with age. Therefore it could be expected that lipid soluble drugs slightly bound to plasma proteins (Bregnate et al., 2000), so danofloxacin would posses larger volume of distribution in adults than neonates. Also development of fore stomach with age increases $\mathrm{Vd}$ as lipid soluble, non ionized drugs as flouroquinolones passively diffuse and accumulate into rumen when administered parentally (Gonzalez, et al., 2001).

Our findings of maximum serum concentrations of danofloxacin $\left(\mathrm{C}_{\max }\right)$ after a single IM injection of $1.25 \mathrm{mg} \mathrm{kg}^{-1}$ to buffaloe calves was ranged from $0.363-0.541 \mathrm{ug} \mathrm{ml}^{-1}$,this was agreed with findings reported in sheep (0.32 ug ml-1) (McKellar et al., 1998), in goats $\left(0.33 \mathrm{ug} \mathrm{ml}^{-1}\right.$ ) (Atef et al., 2001) and in camels( $0.491 \mathrm{ug} \mathrm{ml}^{-1}$ ) (Aliabadi et al., 2003b). Danofloxacin was rapidly absorbed from site of IM injection as indicated by short absorption half-life $\left(\mathrm{t}_{0.5(\mathrm{ab})}\right)$ of $0.421-0.426 \mathrm{~h}$. 
The elimination half life $\left(\mathrm{t}_{0.5(\mathrm{e})}\right)$ after $\mathrm{IM}$ administration was significantly longer in one-month old calves $(8.325 \mathrm{~h})$ than that of twomonths old $(7.978 \mathrm{~h})$.and in one year $(0.540 \mathrm{~h})$ This difference may be attributed to the lower rate of metabolism in the former. After IM injection, $\mathrm{t}_{0.5(\mathrm{el})}$ was significantly longer than that $(3.792-5.802 \mathrm{~h})$ calculated after i.v. injection. This may be due to the result of continued absorption of danofloxacin from the site of IM. injection during the elimination phase, thereby, prolonging the $\mathrm{t}_{0.5(\mathrm{el})}$ of the drug. Absorption limits drug elimination (Gibaldi and Perrier 1982). Also this result is supported by longer MRT after i.m. (9.974-15.565 h) than after i.v. injection (5.334-8.127 h).

The invitro protein binding tendency of danofloxacin to serum proteins was ranged from $6.678-13.572 \%$. This indicated that the drug is slightly bound to serum proteins. It was stated that fluoroquinolones binding to serum proteins is relatively low up to $30 \%$ (Wise et al., 1984). The bioavailability (F) of danofloxacin after i.m administration in buffalo calves (94.366-98.136 \%) indicates a high extent of absorption. MIC of danofloxacin was $0.125 \mathrm{ug} / \mathrm{ml}$ for bovine isolates of Pasteurella multocida, Pasteurella haemolytica and Haemophilus somnus the most important respiratory pathogens of cattle (Glies et al.,1991). Based on MIC previously mentioned it is concluded that the pharmacokinetic parameters in this study at a dose level of $1.25 \mathrm{mg} / \mathrm{kg}$ bwt once daily could be an adequate therapeutic dosage regimen for treatment of buffalo calves infected with susceptible pathogens 


\section{REFERENCES}

- Aliabadi, F.S. and Lees, P. (2001): Pharmacokinetics and pharmaco-dynamics of danofloxacin in serum and tissue fluids of goats following intravenous and intramuscular administration. Am. J. Vet. Res., 62(12): 1979-89.

- Aliabadi, F.S. and Lees, P. (2003): Pharmacokineticpharmacod-ynamic integration of danofloxacin in the calf. Res. Vet. Sci., 74(3): 247-59.

- Aliabadi, F.S., Ali, B.H., Landoni, M.F. and Lees, P. (2003 a): Pharmacokinetics (PK), Pharmacodynamics (PD) and Pk-PD Integration of Danofloxacin in Sheep Biological Fluids. Antimicrob. Agents Chemother., 47(2): 626-635.

- Aliabadi, F.S., Landoni, M.F. and Lees, P. (2003b): Pharmacokinetics and PK-PD modeling of danofloxacin in camel serum and tissue cage fluids. Vet. J., 165: 104-118.

- Appelbaum, P.C. and Hunter, P.A. (2000): The fluoroquinolone antibacterials: past, present and future perspectives. International J. Antimicrob. Agents, 16: 5-15.

- Atef, M., El-Gendi, A.Y. Amer, A.M.M. and El-Aty, A.M. (2001): Some pharmacokinetic data for danofloxacin in healthy goats. Vet. Res. Commun., 25(5): 367-77.

- Baggot, J.D. (1978): Some aspects of clinical pharmacokinetics in veterinary medicine. J. Vet. Pharmacol. Therap., 1: 5-17.

- Bennett, J.V., Brodie, J.L., Benner, E.J. and Kirby, W.M.M (1966): Simplified, accurate method for antibiotic assay of 
clinical specimens. Applied Microbiol., 14(2): 170-177.

- Bregnate et al., (2000): Portein binding of fluoroquinolones applied to live -stock and commpainion animals . J. of Vet .Pharmcology and Therapeuties 23 ( Suppl .1).

- Brown, S.A. (1996): Fluoroquinolones in animals health. J. Vet. Pharmacol. Therap., 19: 1-14.

- Craig, A.W. and Suh, B. (1980): Protein binding and the antibacterial effects: Methods for determination of protein binding. In: V. Lorian (ed.), Antibiotics in Laboratory Medicine, (Williams and Wilkins, Baltimore, MD), 265-297.

- Frenandez-varon, E., Ayala I.; Marin, P., carrion A, Martos, N., Escuder,E,And Carceles, CM(2006): Pharmacokintics of danofloxacin in horse after intravenous, intramuscular and intragasrtic administration. Equine Vet. J. 38 (4) : 342 - 346.

- Galinsky, R.E. and Svensson, C.K. (1995): Basic pharmacokinetics. In: J.P. Remington (ed.), The Science and Practice of Pharmacy, $19^{\text {th }}$ Ed, (Mack Publishing Company, Easton, PA), 724-740.

- Gibaldi, M. and Perrier, D. (1982): Pharmacokinetics, $2^{\text {nd }} e d$. Marcel Dedder, NewYork.

- Giles,cj., Magonigle, RA., Grimshaw, WT., Tanner, AC., Risk, JE., Lynch, MJ and Rice ,JR (1991): Clinical pharmacokinetics of parenterally administered danofloxacin in cattle .J Vet.Pharmacol Ther.,14(4):400-410.

- Gips, M. and Soback, S. (1996): Norfloxacin nicotinate pharmacokin-etics in unweaned and weaned calves. J. Vet. Pharm. Therap., 19: 130-134.

- Gonzalez, F., Rodrigues, C., Nieto, J., De Vicente, M.L., San 
Andres, M.D. and San Andres, M.I. (1997): Age-related differences in norfloxacin pharmacokinetics behavior following intravenous and oral administration in sheep. The Veterinary Quarterly, 19: 145-150.

- Gonzalez, F. San Andres, M. I Noeto J. San Andres. M. D Waxaman, S. De Vicente, M. I . Lucas J.J \& Rodriguez. C. (2001): Influence of ruminal distribution on norfloxacin pharmacokineties in adult sheep . J. of Vet .Parmcology and Therapeuties 24, $241-245$.

- Hannan, P.C.T., O'Hanlon, P.J. and Rogers, N.M. (1989): In vitro evaluation of various quinolone antibacterial agents against veterinary mycoplasmas and porcine respiratory bacterial pathogens. Res. Vet. Sci., 46: 202-211.

- Hooper, D.C. and Wolfson, J.S. (1985): The fluoroquinolones: pharmacology, clinical uses and toxicities in humans. Antimicrob. Agents Chemother., 28: 716-721.

- Kaartinen, L., Panus, S. and Pyorala, S. (1997): Pharmacokinetics of enrofloxacin in newborn and one-weekold calves. J. Vet. Pharm. Therap., 2o: 479-482.

- Kietzmann, M. and Loscher, W. (1990): Pecularities of pharmacokin-etics in young animals. Berl. Munch. Tierarztl Wochenschr, 103(8): 277-82.

- McKellar, Q.A., Gibson, I.F. and McCormack, R.Z. (1998): Pharma-cokinetics and tissue deposition of danofloxacin in sheep. Biopharm. Drug Dispos., 19(2): 123-9. 
- Mevius, D.J., Breukink, H.J., Guelen, P.J.M., Jansen, T. and De Greve, B. (1990): Pharmacokinetics, metabolism and renal clearance of flumequine in veal calves. J. Vet. Pharm. Therap., 13: $159-169$.

- Neu, H.C. (1991): Synergy and antagonism of combinations with quinolones. Eur. J. Clin. Microbiol. Infect. Dis., 10: 255 261.

- Shem-Tov, M., Ziv, G., Glickman, A. and Saran, A. (1997): Pharma-cokinetics and penetration of danofloxacin from the blood into the milk of ewes. Vet. Res., 28(6): 571-9.

- Short, C.R. (1984): Drug disposition in neonates, J of American verterinary, Association, 184, 1161 - 1162

- Short, C.R. and Davis, L. E. ( 1970): Perinatal devlopment of drug metablising enzyme activity in swine. $\mathbf{J}$ of pharmacology and experimental theraputics / $74,185-196$.

- Snedecor, G.W. and Cochran, W.G. (1976): Statistical methods. $6^{\text {th }}$ Ed. Ames, Iowa, USA, pp. 502-503

- Thomas, V.,Deleforge, J. and Boisrame,B. (1994): Pharmacokinetics of marbofloxacin in pre-ruminant and ruminant cattle. Proceeding of the $6^{\text {th }}$ International Congress of the European Association of Veteri-nary Pharmacology and Toxicology (EAVPT). Edinburgh, UK, 60 p.

- Vancutsem, P.M., Babish, J.G. and Schwark, W.S. (1990): The fluoroquino-lone antimicrobials, structure, antimicrobial activity, pharmacokinetics, clinical use in domestic animals and toxicity. Cornell Veterinarian, 80: 173-186. 
- Waxmans S., San Andres MD, Gonzalez E, San Andres MI, De Lucas JJ \& Rodringuz C. (2004): Age - related changes in the pharmacokinetics of marbofloxacin after intravenous administration in goats . J. of Vet .Parmcology and Therapeuties : 27 (1) : 31-5.

- Wise, R., Lockley, R. and Dent, J. (1984): Pharmacokinetics and tissue penetration of enoxacin. Antimicrob. Agents Chemother., 26: 17-19.

- Wolfson, J.S. and Hooper, D.C. (1989): Fluoroquinolones antimicr-obial agents. Lin. Microbial. Rev., 2: 378-424.

تأثير العمر على المسار الحركي لعقار الدانوفلوكساسين في عجول الجاموس المصري عبل الناصر عبد الفتاح مطيع الجندي و محد عبل الله تهامى قسم الأدوية - كلية الطب البيطري جامعة بنى سويف

أجريت هذه الدراسة على عدد خمسة من كل من عجول الجاموس عمر شهر , شهرين وعمر سنة. حيث تم إعطائهم عقار الدانوفلوكساسين(1.25 مجم/كجم) جرعة واحدة عن طريق الحقن الوريدي وبعد أسبوعين تم إعطائهم جرعة عضلية أخرى من نفس العقار • نم تجميع عينات من الدم على فترات مختلفة من 083,-24 ساعة من بداية الحقن. وقد أظهرت الدراسة انه بعد الحقن الوريدي قد سلك العقار منحنى التركيز بالدم مقابل الزمن مسلك ثنائي الحجرات. وكانت فترة نصف عمر التوزيع

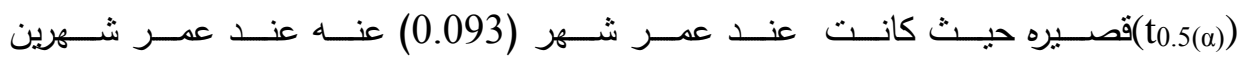
(0.117) و عمر سنه (0.194) ساعة. أما فترة نصف عمر الإخراج (to.5(3) كانت أطول معنويا عند عمر شهر (5.802 ) مقارنتاً بعر شهرين (4.941) و سنه (3.795) ساعة بعد حقن الحيوانات بجرعة 1.25 مجم/كجم على النوالي • وقد كان حجم توزيع العقار للأنسجة (Vdss) أكبر معنويا عند عمر سنه (1.490) منـه عند عمر شـهر و شهرين (1.259 و 1.347) لتر/كجم على التوالي. 
ووجد أن معدل طرح الدانوفلوكساسين (ClB) أكبر في العجول عمر سـنة 20.280 عنه في العجول عمر شهر وشهرين بـ 0.155 و 0.195 لتر/كجم/ساعة على التوالي. أما بعد الحقن العضلي فقد كان أقصى تركيز للدواء في المصل 0.541) 0.434و 0.363 ميكروجرام / مللي تم الوصول اليه وبعد(tmax (tma 1.853 و 1.810 و 1.712 ساعة من الحقن في الأعمار الثلاثة التوالي

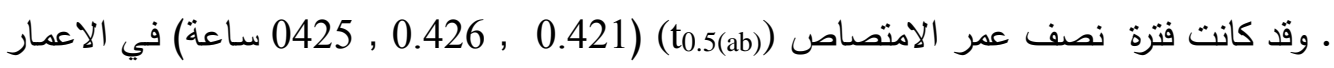
الثناثة علي التوالي • في حين كانت فترة نصف عمر الإخراج (to.5(el) أطول عند عمري شهروشهرين (8.325 و 7.978) مقارنـة بعهر سـنة (6.540) سـاعة على التوالي. وقدـ وجد أن معدل الإتاحسة الحيوية بعد الحقن العضلي (96.37 , 98.14, 94.37 \% ونسبة الارتباط ببروتين الدصل (0.678 و9.176 و 13.572 \%) في الأعمار الثلاثة على التوالي. 